\title{
Dispersal of Streptomycetes in Air
}

\author{
By A. B. LLOYD \\ Department of Agricultural Biology, University of New England, \\ Armidale, N.S.W., Australia 235I \\ (Accepted for publication 4 March 1969)
}

\begin{abstract}
SUMMAR Y
The number of streptomycete propagules trapped from air above a fallow plot depended on the amount of dust in the air. Less than $20 \%$ of the propagules occurred as individuals; the remainder were mostly attached to the surface of airborne soil particles. Thus any action which disturbed the soil surface and launched soil particles into the air, such as the operation of an agricultural implement or a gusty wind, also increased the concentration of airborne streptomycete propagules.

With simulated rain, the first water drops which struck the soil surface launched both individual spores and spores attached to soil particles into the air; with time the water drops washed most propagules from the air.
\end{abstract}

\section{INTRODUCTION}

Streptomycetes are widely distributed in soils, especially in those which are dry and not too acid and those rich in organic matter; here, in propagule numbers, they frequently exceed the combined counts of all other bacteria (Alexander, 196r ; Waksman, 1959). Spread of streptomycetes in soil is by active filamentous growth or by passive movement of spores by soil animals, water or gravity.

Streptomycete spores may also be dispersed aerially. So far, most studies on aerial dispersion have been concerned with the aetiology of certain respiratory diseases associated with inhaling spores of actinomycetes, for example, farmer's lung disease (Gregory \& Lacey, 1963). Here, millions of actinomycete spores per g. of hay were liberated into the air when mouldy hay was shaken. Less is known of the movement of streptomycetes that occur in soil, and the purpose of this study was to examine aerial dissemination of streptomycete propagules originating from soil. The work was also of interest to the South Australian Asthma Foundation, which supplied the Andersen sampler.

\section{METHODS}

Air was sampled above a plot of land formerly used as a nursery for peach trees, then cropped once with beans and finally left fallow for a year. This plot, approximately $40 \mathrm{~m}$. by $21 \mathrm{~m}$., was bordered on one side by an orchard and on the other sides by other cultivated plots, all within the grounds of the Waite Agricultural Research Institute, South Australia.

The soil (Urrbrae loam) is a red-brown earth with a silty loam texture and pronounced fine sand fraction (Piper, 1938). Soil from this plot, when stored, contained approximately $2.0 \times 10^{6}$ streptomycetes and $11 \cdot 5 \times 10^{6}$ other bacteria per g. dry weight 
as determined on dilution-plates of chitin agar (Lingappa \& Lockwood, I962; Lloyd, Noveroske \& Lockwood, 1965) for estimating streptomycetes, and soil agar (Bunt \& Rovira, 1955) for bacteria.

Airborne propagules of streptomycetes were collected above the plot with an Andersen air sampler (Andersen, 1958), placed so that its base was $45 \mathrm{~cm}$. above ground level and near the centre of the field. The operator remained stationary during the time of air sampling to avoid unnecessary disturbance to the soil surface. Petri dishes within the sampler contained chitin agar, sometimes supplemented with acitidione (cycloheximide) at $20 \mu \mathrm{g} . / \mathrm{ml}$., although frequently this was not required, as chitin agar is selective for streptomycetes. After drawing $0.14 \mathrm{~m}^{3}$ of air through the sampler, the Petri dishes were incubated at $28^{\circ}$ for 6 to 8 days. Colonies of streptomycete growing on the chitin agar were then counted.

A sensitive-cup anemometer placed adjacent to the Andersen sampler and with the cups $85 \mathrm{~cm}$. above ground level measured windspeed during each sampling period, while rainfall was recorded by a gauge some $450 \mathrm{~m}$. distant.

\section{Concentration of propagules in air}

\section{RESULTS}

Air was sampled above the fallow plot at $14.00 \mathrm{hr}$ on 30 separate days between I 3 December 1966 and 17 February 1967 , and at hourly intervals on several selected days. The average number of streptomycete propagules trapped was 157 per $\mathrm{m}^{3}$ of

Table I. Increase in concentration of airborne propagules of streptomycetes after disturbing the soil sufficiently to contaminate the air with dust

Date

4 Jan.

5 Jan.

26 Jan.

26 Jan.

I Feb.

I4 Feb.
Soil treatment

Undisturbed soil

Dust raised by a cultivator operating in an adjacent field some $30 \mathrm{~m}$. windward of air sampler

Undisturbed soil

Soil lightly raked $8 \mathrm{~m}$. windward of air sampler

Undisturbed soil

Soil lightly raked $8 \mathrm{~m}$. windward of air sampler

As above but in gusty wind

Undisturbed soil

Cultivator operating on windward side of air sampler

Cultivator operating on leeward side of air sampler

Cultivated soil lightly raked on windward

side of air sampler

$3 \mathrm{hr}$ later without further disturbance of soil

$9 \mathrm{hr}$ later without further disturbance of soil

$\begin{array}{cc}\begin{array}{c}\text { Wind } \\ \text { speed } \\ (\mathrm{m} . / \mathrm{sec} .)\end{array} & \begin{array}{c}\text { Airborne } \\ \text { propagules } \\ \left(\mathrm{m} .^{3} \text { air) }\right.\end{array} \\ I \cdot 4 & \mathrm{I} 29 \\ I \cdot 4 & 1043 \\ & \\ 2 \cdot 5 & 36 \\ 3 \cdot 3 & 643 \\ I \cdot 5 & 14 \\ I \cdot 0 & 364 \\ 2 \cdot I & 1857 \\ I \cdot 2 & 0 \\ I \cdot 2 & 1270 \\ I \cdot 2 & 764 \\ I \cdot 7 & 6715 \\ I \cdot 7 & 200 \\ I \cdot 0 & 98 \\ & \end{array}$


air, while the highest number trapped at any one sampling time was 1,043 per $\mathrm{m}^{3}$ of air; the lowest was o on one day only (Fig. I). Concentration of propagules in air sampled once a day at $\mathrm{I} 4.00 \mathrm{hr}$ did not seem directly related to either windspeed as measured during air sampling (Fig. I) or the daily rainfall, although, as shown later, simulated rain had a marked effect. Nor was the concentration of propagules consistently higher at any one time of day, except in the evening, when the number often increased with the onset of the local 'gully wind' characteristic of that area.
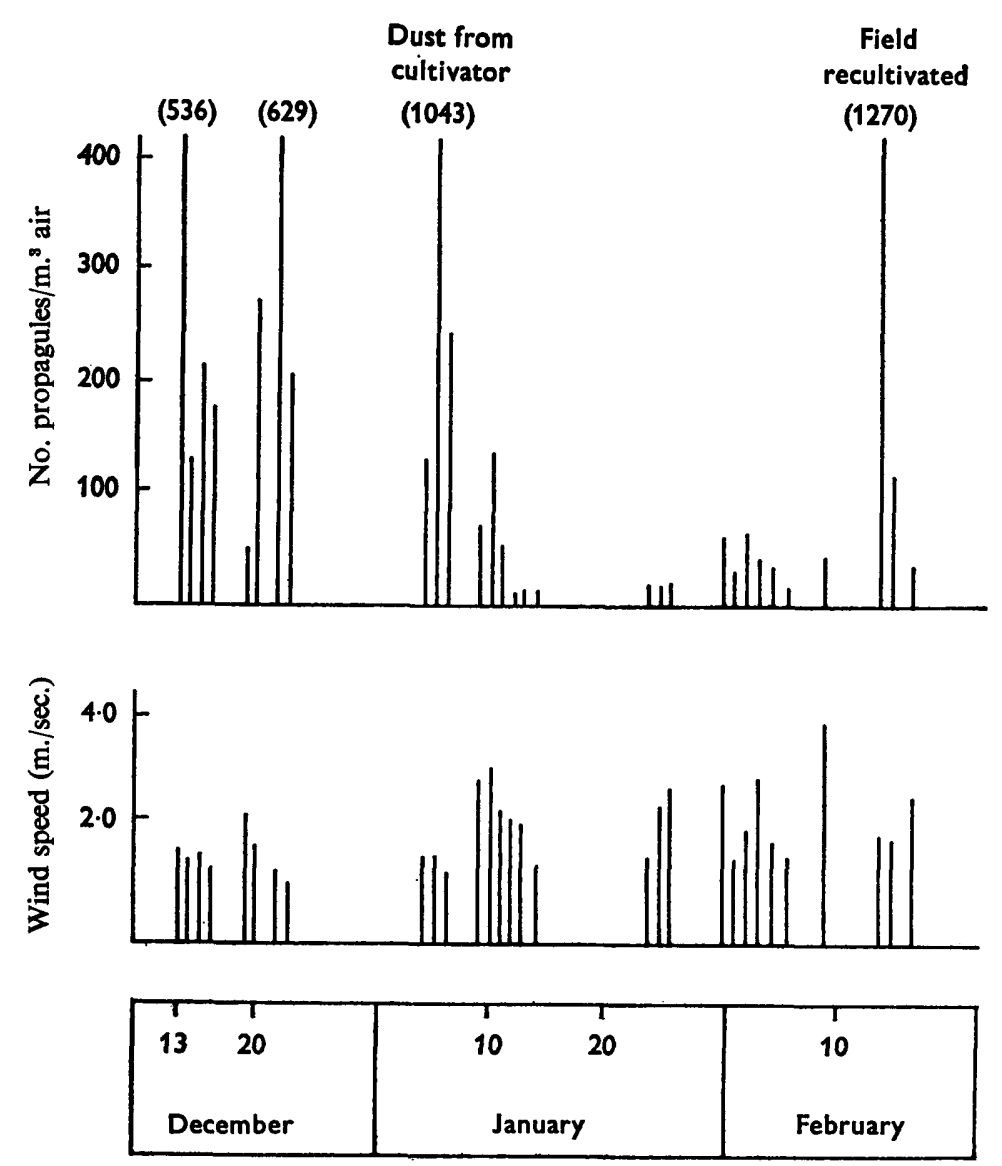

Fig. I. Numbers of streptomycete propagules trapped from air above a fallow field on 30 separate days. Mean windspeeds during sampling periods are given as histograms below the propagule counts. Gaps are periods when air was not sampled.

Whenever dust contaminated the air, concentration of airborne propagules increased. Thus on 5 January a tractor-drawn cultivator, operating in an adjacent orchard, raised dust which drifted across the sampling site and propagule counts in the air reached the peak of $1043 / \mathrm{m}^{3}$ (Fig. I, Table I).

Several other small experiments demonstrated that whenever soil was disturbed sufficiently to raise dust the number of airborne propagules of streptomycetes increased also (Table I). Thus when the surface of soil $8 \mathrm{~m}$. to the windward of the air sampler 
was lightly raked, the concentration of airborne propagules increased from I4 to $364 / \mathrm{m}^{3}$. Then by chance the wind became gusty and propagule concentration increased to $1857 / \mathrm{m}^{3}$. Later the same fallow field was cultivated and when the freshly cultivated soil was lightly raked on the windward side of the air sampler, airborne propagules of streptomycetes increased from o to the high value of $6715 / \mathrm{m} .^{3}$. Three hours later, without further disturbance of the cultivated soil, concentration of airborne propagules was $200 / \mathrm{m}^{3}$ and after $9 \mathrm{hr}, 98 / \mathrm{m}^{3}$.

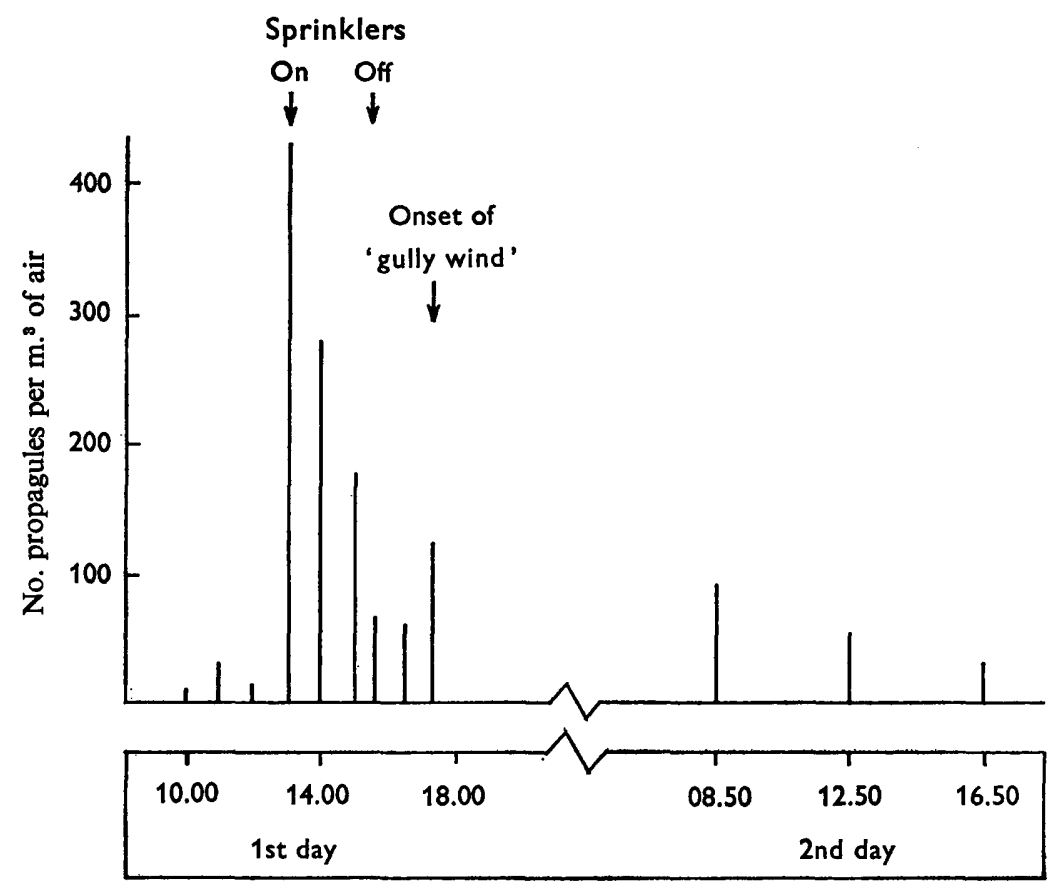

Fig. 2. Numbers of streptomycete propagules trapped from air above a fallow field before, during and after sprinkler irrigation. Gaps are periods when air was not sampled.

\section{Effect of simulated rain on concentration of airborne propagules}

The period between mid-December and mid-February is part of the dry season in South Australia: $33 \mathrm{~mm}$. rain fell during that period in 1966-67. Therefore, to simulate rain, five sprinklers were used to apply water drops to the soil surface, and air was sampled at hourly intervals.

Concentration of streptomycete propagules in air above the sampling site just prior to watering was $20 / \mathrm{m}^{3}$ of air (Fig. 2). This increased to $436 / \mathrm{m} .{ }^{3}$ immediately after turning on the sprinklers. Thereafter, the concentration of airborne propagules decreased steadily throughout the period of simulated rain until it reached $7 \mathrm{I} / \mathrm{m} .^{3}$ when the water was turned off, some $2 \frac{1}{2} \mathrm{hr}$ later (Fig. 2). For the remaining part of the afternoon the number of propagules remained low until the onset of the local 'gully wind' in the evening, when propagule numbers again increased. The following day was extremely hot, the soil surface dried out rapidly and a crust formed; concurrently the concentration of airborne propagules decreased until it reached $28 / \mathrm{m}^{3}$ in the late afternoon. 


\section{Adherence of airborne spores to dust particles}

The Andersen sampler is so designed that it separates particles of similar density into separate size ranges as they are collected on the surface of agar in a series of six Petri dishes (Andersen, 1958).

From all the air samples collected above the fallow field, $44 \%$ of the trapped propagules of streptomycetes appeared in stage $\mathrm{I}$ of the sampler ( $>9 \mu$ particle size), whereas only $17 \%$ appeared in stages 5 and 6 combined $(<2 \mu)$. Further, if only the the air samples collected above undisturbed soil are considered, then $55 \%$ of all propagules appeared in stage $I$ of the air sampler, and only $19 \%$ in stages 5 and 6 combined.

If a streptomycete spore is assumed to be spherical, of unit density and with diameter $<2 \mu$, then less than $20 \%$ of all streptomycete propagules collected from air occurred as individual spores, i.e. those trapped in stages 5 and 6 , whereas some $80 \%$ were either attached to dust particles or occurred in spore clumps. It is more likely that the former is true, for when agar dishes were taken from stage $I$ of the sampler and examined with a microscope, there was frequently a small grain of soil at the centre of each developing streptomycete colony. No such grains appeared in stages 5 and 6 . Thus, it seems that most streptomycetes were aerially transported on fine soil particles, and relatively few as individual spores.

\section{DISCUSSION}

In air above a fallow plot most airborne propagules of streptomycetes were present not as individual units, but adhering to the surface of fine soil particles. Gregory \& Lacey (1963) shook hay in a wind-tunnel and then captured actinomycete propagules, sampling the air at a rate similar to mine. Some $50 \%$ of all actinomycete propagules trapped from air were as individual spores, hence when actinomycetes grow on hay and then sporulate, the spores are liberated into the air mainly as individuals.

Aerial dispersal of streptomycete spores from soil is different, for within the soil streptomycetes grow vegetatively for short periods, sporulate and then the vegetative mycelium disappears, leaving behind localized regions of high spore concentration (Lloyd, 1969). The spores may become dispersed by animal movement and such passive means as water movement and gravity; but they frequently adhere to the surface of soil particles. It is in this attached state that most streptomycete spores are aerially dispersed. Thus any action which raises soil particles from the soil surface will therefore launch into the air streptomycete spores absorbed to the dust particles.

Simulated rain initially increases the concentration of streptomycete propagules in air. Apparently the first water drops, striking the soil surface, launch both individual spores and spores adhering to soil particles into the air. But with time the water drops wash propagules from the air.

\section{REFERENCES}

AleXANDer, M. (1961). Introduction to Soil Microbiology. London: John Wiley and Sons.

ANDERSEn, A. A. (1958). A new sampler for the collection, sizing and enumeration of viable airborne bacteria. J. Bact. 76, 471 .

Bunt, J. S. \& RovirA, A. D. (1955). Microbial studies of subantarctic oils. J. Soil Sci. 6, i 19. 
Gregory, P. H. \& LACEY, M. E. (1963). Mycological examination of dust from mouldy hay associated with farmer's lung disease. J. gen. Microbiol. 30, 75.

LINGAPPA, Y. \& LockWOOD, J. L. (1962). Chitin media for selective isolation and culture of actinomycetes. Phytopathology 52, 317.

LLoYd, A. B. (1969). Behaviour of streptomycetes in soil. J. gen. Microbiol. 56, 165.

LLoYd, A. B., Noveroske, R. L. \& LockwOod, J. L. (1965). Lysis of fungal mycelium by Streptomyces spp. and their chitinase systems. Phytopathology 55, 87I.

PIPER, C. S. (1938). The red-brown earths of South Australia. Trans. R. Soc. S. Aust. 62, 53.

Waksman, S. A. (1959). The Actinomycetes. I. Nature, Occurrence, and Activities. Baltimore: The Williams and Wilkins Co. 